UDC 624.131: 624.154

\title{
RESIDENTIAL BUILDING'S DEFORMATION ON PILE FOUNDATION
}

\author{
Vynnykov Yuriy $^{1^{*}}$, Manzhalii Sergiy ${ }^{2}$ \\ ${ }^{1}$ Poltava National Technical Yuri Kondratyuk University https://orcid.org/0000-0003-2164-9936 \\ ${ }^{2}$ Poltava National Technical Yuri Kondratyuk University https://orcid.org/0000-0002-5819-6056 \\ *Corresponding author E-mail: vynnykov@ukr.net
}

\begin{abstract}
A considerably distinctive deformed five-storeyed three-section brick residential house erected over 40 years ago on driven prismatic piles combined by a strip grid foundation by a standardized project is under investigation. The geotechnical monitoring results of the building's technical condition are presented. Methods and results of the instrumental control analysis of the piles' actual length and visual evaluation of their integrity are presented. The causes of the foundations base's excess deformation were determined: the inability of the piles' tips to reach the designed mark; the piles' destruction during their immersion in dense sands; rupture of the primary thermal network, which led to "negative friction" effect on the piles' lateral surface, etc.
\end{abstract}

Keywords: soil base, sand, soft soil, driven prismatic pile, grid foundation, settlement, crack, tension bar, engineering status of the building, geotechnical monitoring.

\section{ДЕФОРМАЦІї ЖИТЛОВОГО БУДИНКУ НА ПАЛЬОВИХ ФУНДАМЕНТАХ}

\author{
Винников Ю.Л.1*, Манжалій С.М.² \\ ${ }^{1}$ Полтавський національний технічний університет імені Юрія Кондратюка \\ ${ }^{2}$ Полтавський національний технічний університет імені Юрія Кондратюка \\ *Адреса для листування E-mail: vynnykov@ukr.net
}

Подано результати геотехнічного моніторингу технічного стану достатньо характерного деформованого п'ятиповерхового трисекційного цегляного житлового будинку, зведеного понад 40 років тому за типовим проектом на забивних призматичних палях, об'єднаних стрічковим залізобетонним ростверком. Виконано візуальне та інструментальне обстеження несучих будівельних конструкцій. Доведено, що конструктивну схему будівлі не можна вважати жорсткою. Виявлено дефекти й пошкодження, що впливають на несучу здатність та довговічність окремих конструктивних елементів і будівлі в цілому, зокрема вертикальні тріщини із шириною розкриття до 20 мм у зовнішніх та внутрішніх стінах, тріщини в збірних перемичках у підвалі, обрив попередньо напружених тяжів та ін. Визначено фактичні параметри основ і фундаментів. Описано методику та викладено результати аналізу інструментального контролю фактичної довжини паль і візуального оцінювання їх цілісності. Розраховано проектну та фактичну несучу здатність паль і осідання їх основ. Установлено причини наднормових деформацій основ фундаментів, зокрема: неможливість досягнути вістрями паль проектної позначки, що призвело до значного зменшення їх несучої здатності; руйнування паль у процесі їх занурення у щільні піски намиву; порив магістральної теплової мережі, котрий призвів до появи ефекту «негативного тертя» за бічною поверхнею паль; дія інерційних сил від вибухів у кар'єрі. Технічний стан пальових фундаментів визначено як незадовільний. Розроблено рекомендації щодо подальшої експлуатації будівлі. Обрано конструктивно-технологічне рішення посилення ії фундаментів, зокрема посилення пальових фундаментів підведенням під існуючі ростверки монолітної залізобетонної плити товщиною не менше 400 мм, захватками та поетапно. Для включення плити «в роботу» одразу після ії влаштування передбачено ущільнення основи під плитою.

Ключові слова: грунтова основа, пісок, слабкий грунт, забивна призматична паля, монолітний залізобетонний ростверк, осідання, тріщина, металевий тяж, технічний стан будівлі, геотехнічний моніторинг. 


\section{Introduction}

The group of deformed structures [1] includes buildings that have undergone unacceptable settlement and deformation during the period of their construction and especially exploitation, which, however, do not interfere with its operation but limiting the possibility of its strengthening in time.

The absolute and specific settlement of the foundation's base, heeling and other deformations of the buildings and structures occur out of fairly typical errors, which are usually combined into four groups [17], in:

- geotechnical surveys (insufficient field and laboratory investigation, wrong determination of soil properties, neglecting of strata, layers, soft soil lenses within the base of a building, incorrect estimation of spatial heterogeneity of soil massif, neglecting of annual and seasonal fluctuations in groundwater level, other dangerous geotechnical processes, etc.) [1 - 9];

- poor design (in particular, the failure to account for the specific properties of soils within the compressible strata of the base, variation of the soil base's physical and mechanical properties, underestimation of the composition and essence of the load transfer on the foundation and base, the form complexity and deficient building's rigidity, cancellation or decreasing the number of pile static tests at the site, etc.) [1-14];

- violations of the building operations rules (such as the use of so-called "critical technologies" of soil structure distortion within its cyclic wetness change, partial freezing of foundation soil, poor arrangement of sand and soil beds, excess soil extraction from the pit, pile driving above the designed mark, undercompaction of the backfill soil in the pit hollows, etc.) [1-8];

- violations of the buildings and structures operation rules (for example, prolonged and accidental leaks from water-bearing communications, unreasonable increase in loads, construction works near the facility in the context of dense urban development, etc.) [1-4].

Constructive and technological solutions for the strengthening or reconstruction for each such object is a complex and relevant task of modern geotechnics, which is made by the investigation results of $[1-3,7]$ :

- regularities of geotechnical conditions change (GTC) of the site and stress-strained state (SSS) of building base;

- design features and operating conditions of the facilities;

- nature and causes of buildings' deformation;

- buildings foundations' stability under operation while its reconstruction (restoration).

\section{Review of the research sources and publications}

Prof. B. Dalmatov considered the settlement of each foundation base to be the sum of five components: settlement due to the compaction of the natural structure soils at the increasing stresses from the foundations' weight; settlement associated with decompression of the upper soil strata that lies below the bottom of a foundation pit, due to the reduction of stresses during excavation; settlement due to the soil squeezing (extrusion) from beneath the foundation caused by the progression of plastic deformations; settlement of the disruption, which progresses due to the soil compressibility increase at its natural structure distortion during execution; settlement caused by changes in the stress state or deformation of the soil base during the building (structure) operation [3, 15].

At the same time, prolonged geodetic surveys of the building's foundations settlement on pile foundations [7-10, 14, 16, 17] showed that both absolute and relative stabilized values of settlement are in most cases smaller than its calculated and normative limit values. Naturally, the deformed structures group includes buildings on pile foundations (foundations that are constructed without soil excavation) slightly less frequently than similar objects on a natural base (foundations built with soil excavation [7]).

In addition to the above, the causes of excessive absolute and relative settlement of pile foundations base (and occurrence and propagation of cracks and other noticeable deformations in load-bearing structures as a consequence) are most often [1 - 10, 14]:

- unjustified application of increasing correction coefficients to the results of compression tests of soft (highly compressive) soils (long geodetic surveys of settlement on soft, including wetted loess soil, indicate that the calculations of settlement should be performed $[7,10,13,14])$;

- catching the bottom tips of piles into strata (layers) of soft soil (furthermore, under these conditions stabilization of settlement can be realized more than 10 - 15 years of building operation $[7,10,14]$ );

- pile driving above the design mark, a characteristic problem is determining the depth of pile driving and the presence of the defect in it;

- overestimation of the piles bearing capacity due to failure to observe the optimum time of its "rest" after immersion or misinterpretation of "load on the pile - its subsidence "graphs;

- excessively close placement of adjacent piles in planar view, which, when driven especially in the sands, leads to "ejection" upwards of previously driven ones, and under the construction load the structure undergoes respective settlement;

- nonuniform loading of piles in the grid's structure, etc.

\section{Definition of unsolved aspects of the problem}

It is problematic to account for the influence of these factors on the magnitude of pile foundations base deformation, especially by methods of classical soil mechanics $[6,12]$. Therefore, the choice of structural and technological solutions for the reinforcement (reconstruction) of each deformed building on the pile foundation is made only after a careful assessment of the technical condition of the object's load-bearing structure and the investigation of the parameters of its base and foundations, by engineering inspection and defining the causes of excess deformations of the foundations' base.

Problem statement 
So, the research aims to evaluate technical condition of load-bearing structures of a sufficiently deformed characteristic (with numerous, mostly vertical, force cracks) full-scale object, five-storeyed three-section brick residential building on driven prismatic piles combined by a strip grid foundation, and determine the parameters of bases and foundations by engineering inspection and defining the causes of excess deformation of the foundations' bases.

\section{Basic material and results}

The research algorithm, the so-called geotechnical monitoring $[3,5]$, included the following steps:

- visual and instrumental inspection of load-bearing structures;

- measurements in the scope required for the verification of these structures' calculations ;

- verification calculations of load-bearing structures;

- assessment of the technical condition of loadbearing structures based on inspection and verification calculations;

- determining the parameters of bases and foundations, including the actual length of piles;

- defining the causes of excessive deformation of the building foundations' base;

- development of recommendations for the further operation of the building and the choice of structural and technological solutions to strengthen its foundations.

The five-storeyed residential building with a basement and a technical floor is located in Horishni plavni, Poltava region. It was erected in 1977 according to a typical project, consists of three-block sections: 87049 / 71 - the left end, which has undergone significant deformations (Figs. 1 and 2); 87-046 - ordinary; 87$048 / 71$ - the right end.

In structural terms, the building is a structure with longitudinal bearing walls. The height of the floors is $2.8 \mathrm{~m}$, and the basement (from the floor to the bottom of the slab panel) is $2.1-2.2 \mathrm{~m}$. The walls are made of solid one and a half silicate brick on a cement-sand mixture. The thickness of the outer longitudinal bearing and end walls without facing is $510 \mathrm{~mm}$. The thickness of the inner longitudinal load-bearing walls with the plaster layer is $400 \mathrm{~mm}$. The load-bearing walls in the basement of the house from the -2.800 to -1.600 mark are made of 2 rows of FBS 24.5.6-T blocks, and of brick masonry higher. Spatial rigidity is provided by the transverse staircase walls and inter flooring discs. The building's structural design can't be considered rigid. The class of consequences of the building $-\mathrm{SS}$ 2 . The main thermal network with a diameter of $2 \times 150$, $125,100 \mathrm{~mm}$ laid through the basement. Its inlet to the basement is located below the left block section (axis 1-2) from the side of the staircase wall. Below the section, there is a $90^{\circ}$ rotation of the pipeline that passes through the entire basement and comes out on the opposite end of the house.

There were defects and damages during the construction and operation of the building affecting the load-bearing capacity and durability of individual elements and the building as a whole, such as:
- vertical cracks with opening width up to $20 \mathrm{~mm}$ in the outer and inner walls;

- pile's destruction due to deviation from the design position;

- cracks in precast spandrel beam in the basement;

- wetting of the basement structures of the building at the exit point of the main thermal pipeline due to its rupture;

- destruction of paving on the perimeter of the building;

- break of pre-stressed tension bars.

Thus, vertical cracks (Fig. 3) were detected at the entire height in the outer load-bearing walls, mainly at the places of the spandrel beam supporting and over (under) the openings.

Cracks are typical for buildings with reinforced concrete spandrel beams that cause deformation of the window unit by turning it as a single rigid element. Cracks indicate significant deformation of the foundations' base of the left end section in the direction of separation from the main part of the building. The cracks propagation significantly reduces the spatial rigidity of the section because, for separated parts of the outer and inner walls, the spatial rigidity is no longer provided by the transverse walls of the stairwell. There are no cracks on the outer and inner walls of the staircase, which confirms the previous statements.

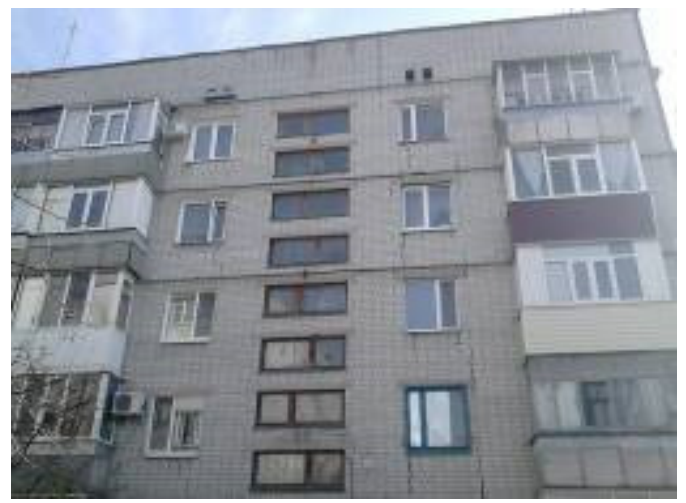

Figure 1 - Fragment of the left block section on the axis $B$

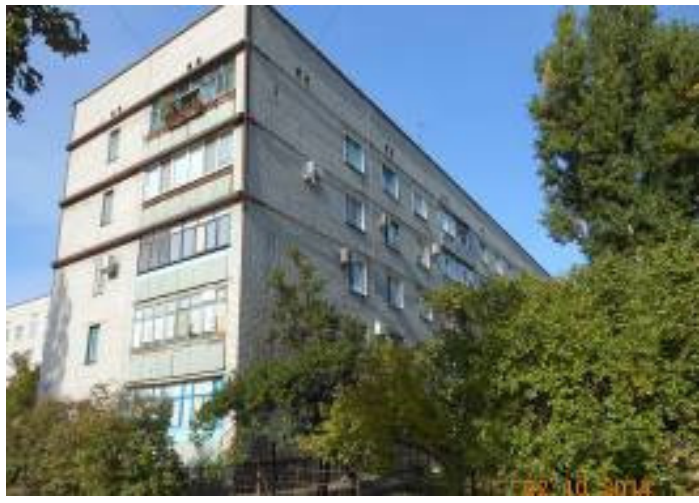

Figure 2 - View of the left side block section in the axes A-B and on the axis $A$ 


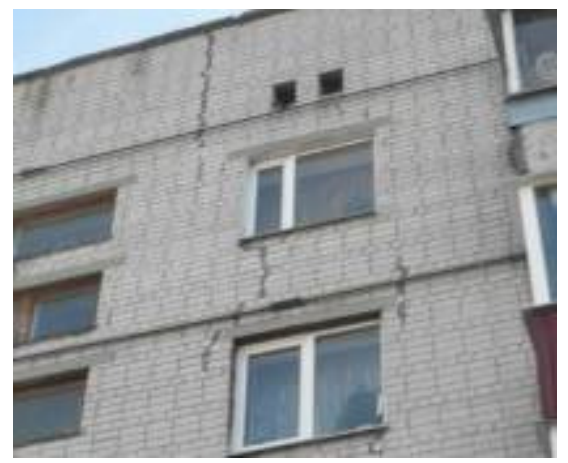

b

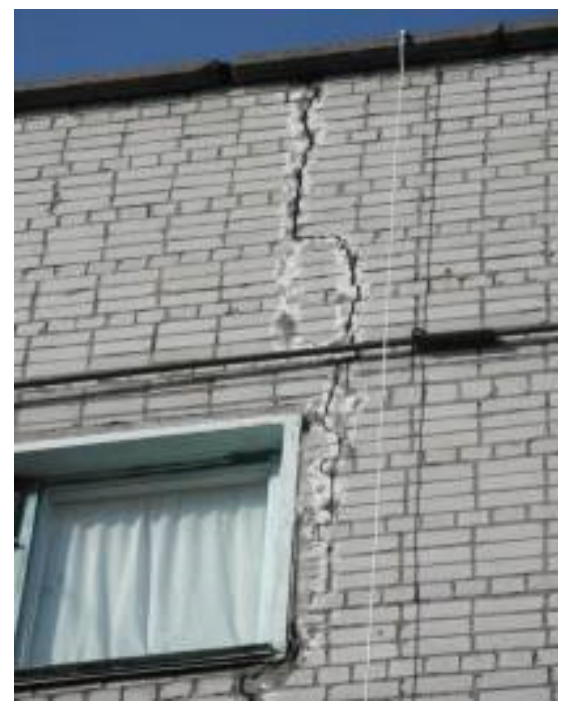

c

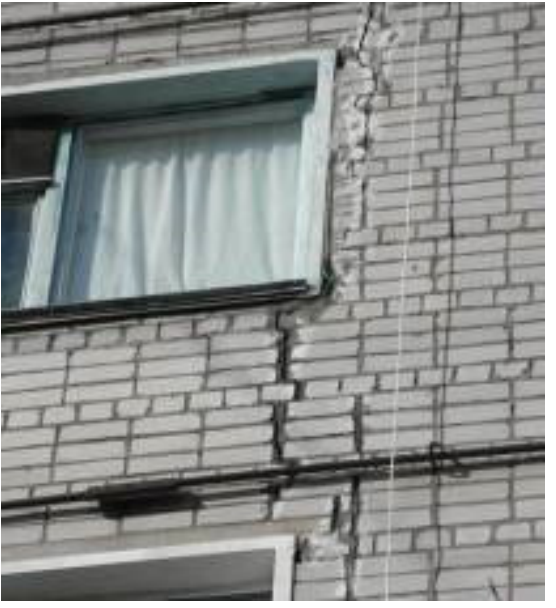

d

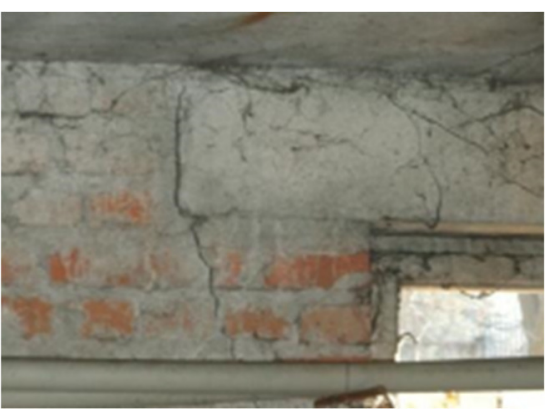

Figure 3 - Vertical cracks with opening width: $\mathrm{a}-7 \mathrm{~mm} ; \mathrm{b}-15 \mathrm{~mm} ; \mathrm{c}-12 \mathrm{~mm} ; \mathrm{d}-4 \mathrm{~mm}$
Minor cracks in the walls and between the floor slabs occurred immediately after the house was occupied in 1977, but it suffered the greatest deformations in 1993 under the left block section I-II, in the axes $1-2$ after the rapture of thermal pipeline in the spot of $90^{\circ}$ turn. At the same time, to reduce deformations, the prestressed tension bars (Figs. 1, 2) of $36 \mathrm{~mm}$ diameter reinforcing bars were arranged with struts to create tension in it. Horizontal beams of the rectangular crosssection of two welded channels No. 24 are installed along the end walls, and the attachment of the weights to the beams is through an equal angle 140x10, which is installed in the corners of the building. Given the fact, that the free length between the points of attachment should not exceed $15-20 \mathrm{~m}$ (in our case it was 67.2 $\mathrm{m})$, the cracks were opened in the future, since at considerable length the elastic absolute deformations in the steel of tension bars are very large. At the level of overlapping of the third and fifth floors, there was a break in the metal tension bar (Fig. 4), indicating a poor design of the reinforcement. Gypsum tell-tales were placed on the inner load-bearing wall, starting from the third floor, in the area of the stairwell. Cracks in it indicate the further development of deformations (Fig. 5). On the end wall of the left block section cracks are missing.

Therefore, the technical condition of the outer and inner bearing walls is classified as unsatisfactory.

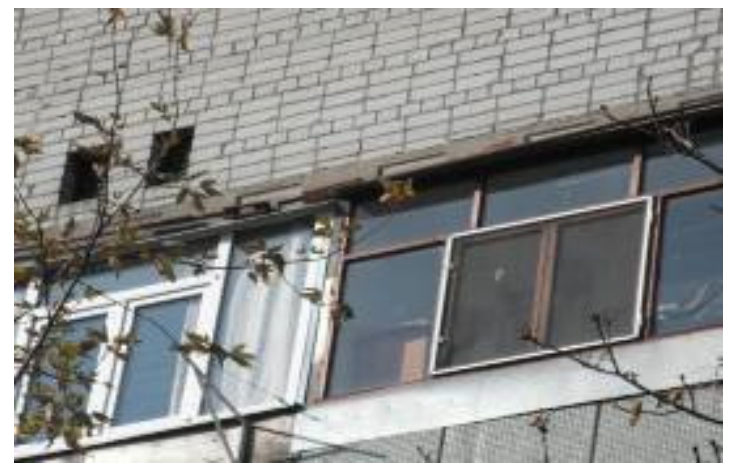

Figure 4 - Break of the upper tension bar along axis $A$ at the level of the fifth floor overlap

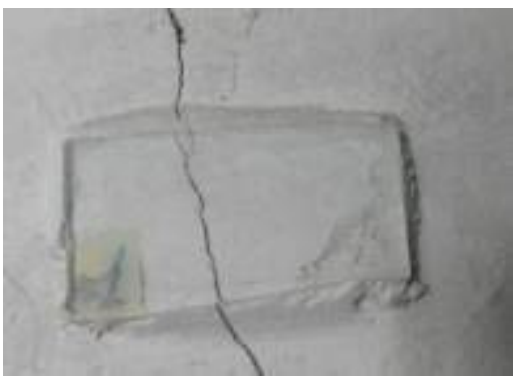

Figure 5 - Crack in the tell-tale (fifth floor)

Overlappings are the precast concrete void slabs 5.4 $\mathrm{m}$ long. There were cracks in the joints between the slabs in the basement and on the fifth floor, some joints unfilled with the mixture, which reduces the spatial rigidity of the building. The technical condition of the overlaps is classified as satisfactory. 
The foundations are driven prismatic piles SNIP 9-35 (9 m length, $350 \times 350 \mathrm{~mm}$ section), combined by a strip grid of $400 \mathrm{~mm}$ height. Under the inner load-bearing wall, the grid width is $400 \mathrm{~mm}$, and under the outer wall, it is $500 \mathrm{~mm}$. The increment of the piles under the inner wall is $1100 \mathrm{~mm}$, under the outer wall is $1360-1530 \mathrm{~mm}$, and under the end walls $-1590-1610 \mathrm{~mm}$.

Lithologically, within the boundary of the site under the bulk layer (EGE-1a) and fine sands (EGE-2c and EGE-2p, respectively, of medium density and dense with modulus of deformation, respectively, $\mathrm{E}=19.5$ and $35 \mathrm{MPa}$ ) with a total depth of about $7 \mathrm{~m}$, there is a layer of buried soils (EGE-3) - layered sandy loams, with layers of silt and clay, fluxional $(\mathrm{E}=6.5 \mathrm{MPa}$, organic matter content $-8 \%$ ), which are underlined by medium-sized alluvial sands of $9-10 \mathrm{~m}$ deep (EGE-4, $\mathrm{E}=45 \mathrm{MPa}$, and from a depth of about $18 \mathrm{~m}-$-- by the clay of the Kharkiv formation. A sand wash on the site for construction was carried out in the the $1970-1973$ period. From the graphs of static probing, it is possible to conclude that these sands have stabilized and selfcompacted by the time of the investigation. Groundwater level (WL) at the time of the survey was $6.8-7.3 \mathrm{~m}$ from the earth's surface. Its annual and seasonal fluctuations reach $1.5 \mathrm{~m}$ from this level.

Unfavorable engineering-geological processes have been identified within site: dynamic impact on sandy soils from career explosions, which can lead to their dynamic liquefaction; mechanical suffusion during the operation of water-bearing communications; rather thick (up to $2.3 \mathrm{~m}$ ) soil with impurities of organic matter.

The project provided for penetrating the buried soil with СНпр 9 - 35 piles, that reached IGE-4. In this case, the calculation revealed that: the load on the pile under the inner and outer bearing wall is 404.5 and $390.6 \mathrm{kN}$, respectively; pile's bearing capacity is $\mathrm{Fd}=1334.8 \mathrm{kN}$; allowable design load $\mathrm{N}=953.4 \mathrm{kN}$; the subsidence of the base of such foundation is $\mathrm{S}=1,44 \mathrm{~cm}$.

Considering the above and the worst possible scenario, under which accompanied by the rapture of the thermal pipeline could have the effect of "negative friction" on the lateral surface of the pile, the magnitude of which can reach $317 \mathrm{kN}$ (soil layers EGE-2c and EGE-2p), allowable calculated load on the pile $\mathrm{N}=$ $499.5 \mathrm{kN}$ which still exceeds the pile load from the structures $404.5 \mathrm{kN}$. Therefore, the actual length of the piles in the foundation was checked. It should be added that during static probing, the probe was not always able to pass the thickness of the washed sands, in particular EGE-2p, which is dense. It is problematic to penetrate these layers with the hammering with a diesel-hammer pile with a cross-section of $350 \times 350$ $\mathrm{mm}$.

Thus, continuity and length control of the piles was performed acoustically using the software package Pile Integrity Tester PIT - W (Pile Dynamics in the USA). The PIT complex - W (US production) has a marginal relative error in determining the linear dimensions of structures of $\pm 5 \%$. The relative error of determining the propagation time of the signal in the frequency range is $\mathrm{f}=1.9 \mathrm{kHz}$ is $\pm 1 \%$. The complex underwent metrological verification in the center of standardization, metrology, and certification. The RIT ${ }^{\text {TM }}$ Solestog is based on the Pulse Reflection Method (PRM). Initially, it sends an impulse that strikes lightly on the surface of the pile. To do this, a special hand hammer is utilized. The impulse-induced acoustic wave propagates along the pile. The pile's shape and its material's quality affect the reflected waves, which are recorded as they return to the surface. All surface vibrations are recorded to obtain information on all major reflected signals. Next, to judge the integrity of the pile, the reflected waves are analyzed, accounting for its nature and intensity.

6 exploratory shafts were made for these tests, and the pile body was cleared by $20 \mathrm{~cm}, 3$ of them located in the damaged left block section (axis I - II), 2 - in the row block section (axis II - III) and 1 - in the right block sections (axis III - IV in Fig. 6). The pile length control process is shown in Figure 7.

To confirm the results of visual and instrumental control of the pile's integrity and its length, the pile heads "cutting" possibility was checked. For this purpose, the pile head's reinforcement design was compared with the actual one (the first $300 \mathrm{~mm}$ of the head were reinforced with $50 \mathrm{~mm}$ grids, and then a 700 $\mathrm{mm}$ spiral began with a $100 \mathrm{~mm}$ shear increments, going into a $200 \mathrm{~mm}$ shear cross spiral). The concrete protective layer was previously removed.

a

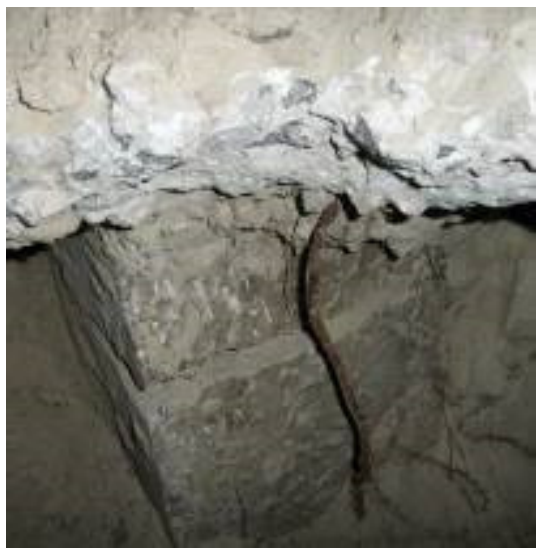

b

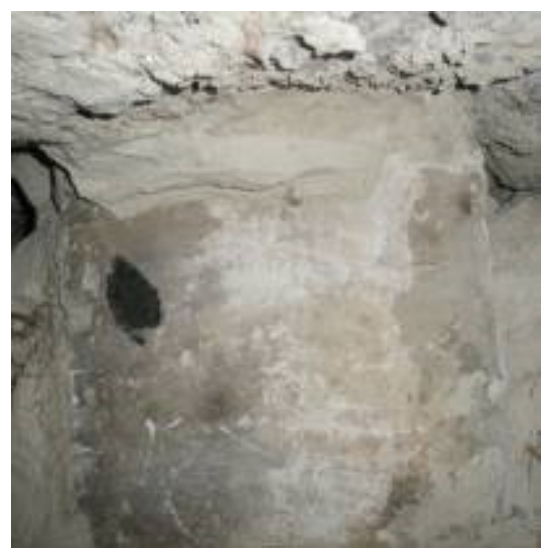

Figure 6 - The piles view as a part of the grid: a №1 (pile №119); b - №2 (pile №105) 


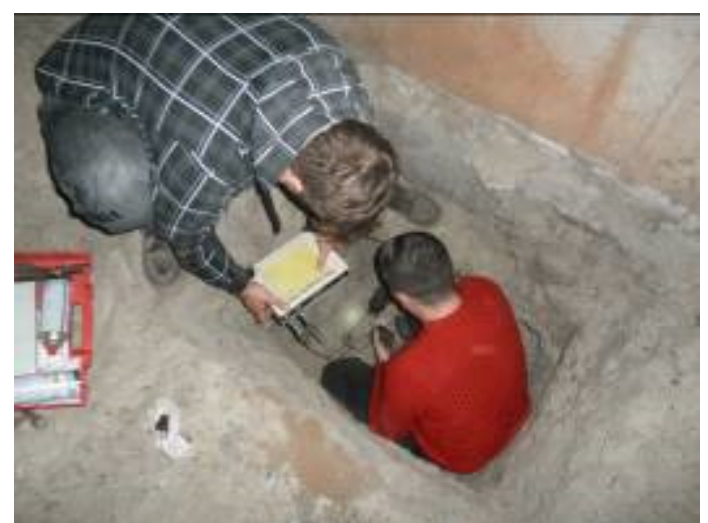

Figure 7 - Performing pile length control work

Compared to the nondestructive testing stage, during the investigation of the pile's reinforcement, the exploration shaft was deepened, revealing cracks in the pile body (Fig. 8). The pile was destroyed since the protective layer of concrete was split in a stretched zone. The concrete in the compressed area split and crumbled. The increment of the transverse reinforcement was $200 \mathrm{~mm}$. It shows that the pile was not driven to the designed mark, it was "cut down". The minimum length of the "cut" part was $600 \mathrm{~mm}$. In this state, the pile does not withstand vertical compressive loads. The results of the instrumental control analysis of the pile's length and visual assessment of their integrity are summarized in Table 1.

Table 1 - Instrumental control results of piles' length and integrity

\begin{tabular}{|l|l|l|}
\hline $\begin{array}{c}\text { Shaft / } \\
\text { pile № }\end{array}$ & $\begin{array}{c}\text { Actual } \\
\text { pile } \\
\text { length, } \mathrm{m}\end{array}$ & Notes \\
\hline $1 / 119 *$ & $\begin{array}{l}\text { Pile de- } \\
\text { stroyed } \\
\text { from the design position while } \\
\text { driving. The pile operates on } \\
\text { eccentric compression due to the } \\
\text { considerable eccentricity of } \\
\text { loading and pile's body deflection } \\
\text { from vertical. The crack opening } \\
\text { in the pile - 40 mm. }\end{array}$ \\
\hline $2 / 105 *$ & 8.5 & - \\
\hline $3 / 9 *$ & 4.5 & - \\
\hline $4 / 77$ & 8.5 & - \\
\hline $5 / 171$ & 6.0 & - \\
\hline $6 / 33$ & 7.5 & - \\
\hline
\end{tabular}

The pile reinforcement check confirms the assumption that part of the pile failed to be driven to the design mark. The piles' lengths discovered in the instrumental survey are true. To establish the possible difference in settlement, a test calculation was performed for pile \# 119 (shaft \# 1) of a 4.5 m length with a cross-section of $350 \times 350 \mathrm{~mm}$. A vertical tie of this pile to the geotechnical column is shown in Fig. 9. a

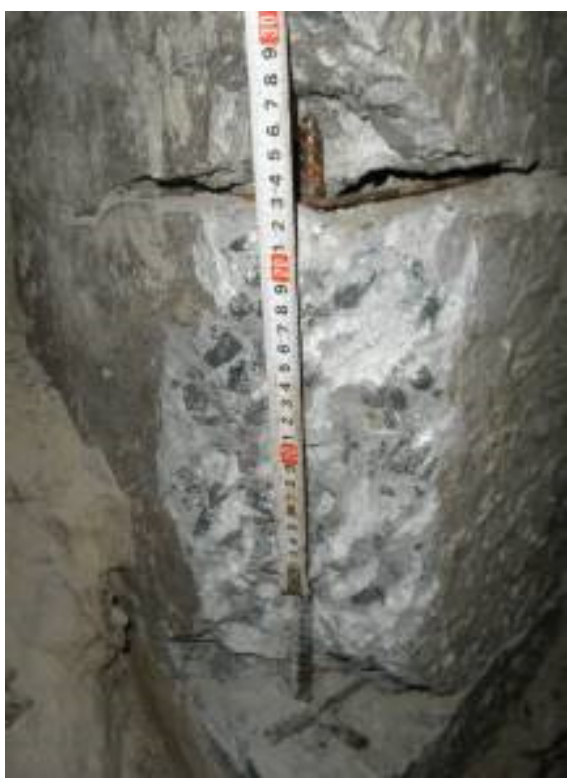

b

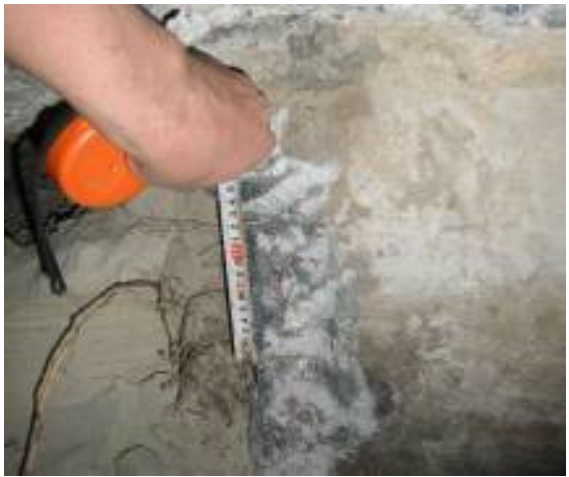

Figure 8 - The piles' view as grid component in pile reinforcement investigation:

a - pile №119 in shaft №1;

b - pile №105 in shaft №2 (the reinforcement increment in the survey was $100 \mathrm{~mm}$, therefore, the pile's tip reached the design mark)

The following results were obtained in the calculation. Settlement of the pile is $S=2.2-2.5 \mathrm{~cm}$ based on the calculation method. Thus, the difference between the settlement of piles with a length of $9 \mathrm{~m}$ and $4.5 \mathrm{~m}$ is about $1 \mathrm{~cm}$, which could not cause actual overdeformation.

However, given the occurrence of "negative friction" effect due to self-compacting and mechanical suffusion in the upper layers of the bulk sands after rupture of the main thermal pipeline, which was intensified by inertial forces from the explosions in the quarry, the bearing capacity of the pile decreased to $\mathrm{Fd}=375.7 \mathrm{kN}$, it is up to $\mathrm{N}=268.0 \mathrm{kN}$, which is less than the vertical force from the structures of the building $404.5 \mathrm{kN}$.

When the permissible load on the pile was exceeded, the pile's foundation base settlement was already in the nonlinear stage, which led to the appearance and development of existing deformations of the building. Provided that if all the piles' tips reached the design mark, then, of course, such deformation would not occur. 


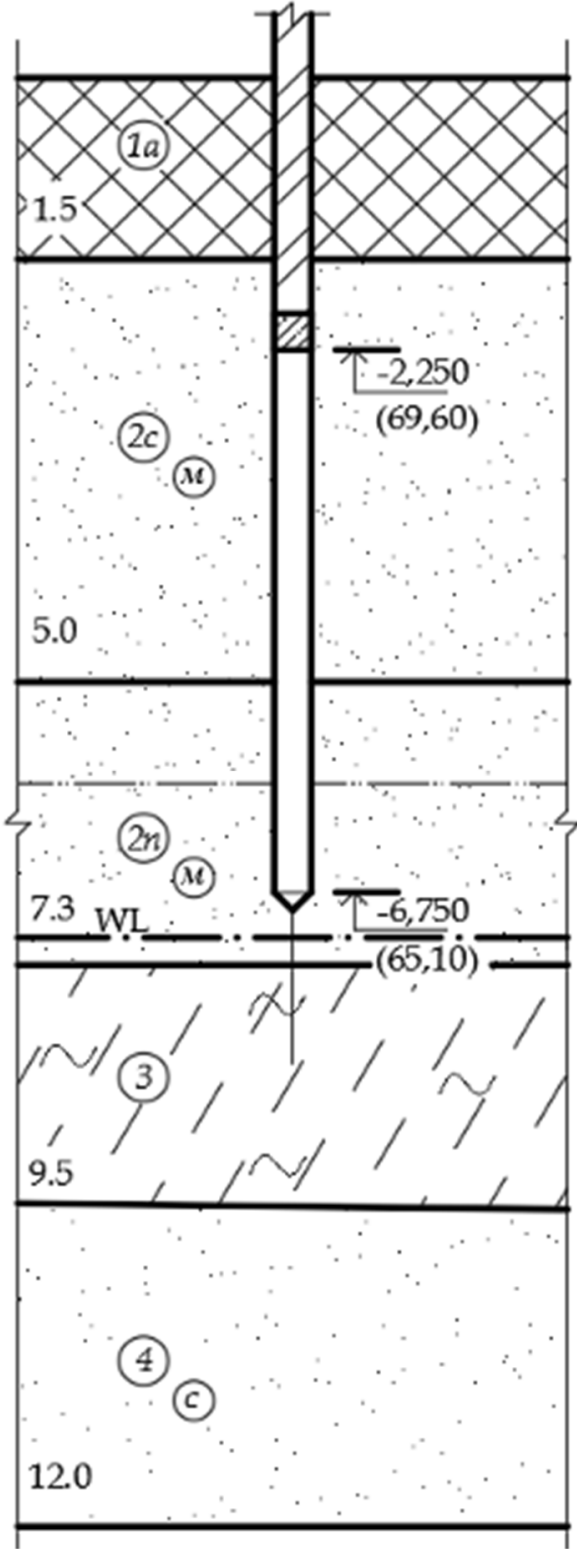

Figure 9 - The vertical tie of the pile to geotechnical column according to SNIP 4.5 - 35

Therefore, the technical condition of the pile foundations of the building was classified as unsatisfactory.

As the survey found that some piles were significantly damaged, the length of others did not correspond to the design, it is not possible to guarantee the absence of water-bearing communications for the future and to eliminate the negative impact of the explosions in the quarry on the wash sands, it was decided to develop a project to strengthen the pile foundations.

It's worth noting that if similar sections of the water supply network crashed in other sections of the building, it would get comparable damage. Therefore, to ensure the prolonged operation of the building for the period of reconstruction and afterward, the decision was made to develop an appropriate project, which would include a set of measures, that would include:
- reinforcement of the pile foundations of the left face block section in the I-II axes by underlaying at least 400 $\mathrm{mm}$ thickness of monolithic reinforced concrete slab under the existing grids. The underlaying of the slab must be done in four stages, starting from axis II, moving to axis I. To put the plate into operation as soon as it is performed, the base under the slab should be compacted by gravel and pounded with vibrating plates;

- strengthen the outer and inner bearing longitudinal walls to prevent the reduction of its spatial rigidity by dividing them into separate blocks (columns) by cracks. For this purpose it is possible to use already existing inefficient metal structures of reinforcement or to execute reinforcement with outer metal linings from rolling profiles;

- to chipper and rip cracks open with M 100 cement sand mixture (alternatively, injection of these cracks with M 100 solution);

- eliminate depressurization of the main thermal pipeline at the exit from the right end block section in axes III-IV;

- replace the metal of main thermal pipelines, which have been in operation for 37 years, since its standard service term is only 30 years and it is not possible to guarantee its hermiticity or to move the pipeline from the basement of the house;

- strengthen reinforced concrete spandrel beam in the inner bearing wall of the basement in axes I-II on axis $\mathrm{B}$;

- restore the protective layer of concrete piles in which their reinforcement was investigated;

- to restore the design perimeter walk along the building and to organize vertical planning of the territory for surface water abstraction.

Finally, it should be noted that such a project was completed and successfully implemented. Now the building is operated normally.

\section{Conclusions}

Thus, according to the results of geotechnical monitoring of the technical condition of a considerably distinctive deformed five-storeyed three-section brick residential house erected over 40 years ago on driven prismatic piles combined by a strip grid foundation by a standardized project, the following conclusions are made.

1. In structural terms, the building is a structure with longitudinal bearing brick walls. Its spatial rigidity is provided by the transverse walls of the staircase, as well as the inter-floor disks. The structural design of the building cannot be considered rigid. The main thermal network passes through the basement of the building.

2. During the erection and operation years, defects and damages occurred in the building's structures affecting both the bearing capacity and the durability of the individual structural units and the whole building, that can be classified as follows:

- vertical cracks with opening widths up to $20 \mathrm{~mm}$ in the outer and inner walls;

- vertical cracks with opening widths up to $20 \mathrm{~mm}$ in the outer and inner walls 
- destruction of the pile due to deviation from the design position;

- cracks in precast spandrel beams in the basement;

- wetting of the building's basement structures at the exit point of the main thermal pipeline due to its rupture;

- the destruction of the building's perimeter paving ;

- pre-stressed tension bars' breakoff.

3. The causes of the occurrence and development of excessive deformations in load-bearing units of the structure are a complex of factors, that includes:

- the inability to reach the design mark by the piles' tips during the construction, which led to a significant reduction of its bearing capacity;

- the destruction of piles during its driving in dense wash sands;

Rания 1. Коновалов, П.А., Коновалов, В.П. (2011). Основания
и фундаменты реконструируемых зданий. Москва: Издво ACB.

2. Полищук, А.И. (2004) Основы проектирования и устройства фундаментов реконструируемьхх зданий. Нортхэмптон: STT; Томск: STT.

3. Улицкий, В.М., Шашкин, А.Г., Шашкин, К.Г. (2010) Геотехническое сопровождение развития городов. Санкт-Петербург: Геореконструкция.

4. Briaud, J.-L. (2013). Geotechnical Engineering: Unsaturated and Saturated Soils. Wiley.

5. Ильичев, В.А., Мангушев, Р.А. (Ред.) (2014). Справочник геотехника. Основания, фундаменты и подземные сооружения. Москва: Изд-во АСВ.

6. Katzenbach, R., Leppla, S., Seip, M. \& Kurze, S. (2015) Value Engineering as a basis for safe, optimized and sustainable design of geotechnical structures. Proc. of the XVI ECSMGE Geotechnical Engineering for Infrastructure and Development. Edinburg, $601-606$.

https://doi/abs/10.1680/ecsmge. 60678

7. Зоценко, М.Л., Винников, Ю.Л. (2019). Фундаменти, що споруджуються без виймання трунту. Полтава: ПолтНТУ.

8. Тугаенко, Ю.Ф. (2008) Процессы деформирования грунтов в основаниях фундаментов, свай и свайных фундаментов. Одесса: Астропринт.

9. Fleming, K., Weltman, A., Randolph, M. \& Elson, K. (2008) Piling Engineering. London: New York: Taylor and Francis.

10. Сотников, С.Н. (1987). Строительство и реконструкция фундаментов зданий и сооружений на слабых грунтах. (Автореф. дис. д-ра техн. наук). ВНИИОСП, Москва.

11. Won, J.Y. (2009) A probabilistic aproach to estimate one-dimensional consolidation settlements. Proc. of the 17th Intern. Conf. on Soil Mechanics and Geotechnical Engineering. Olexandria, Egypt, 2009. - Amsterdam, Berlin, Tokyo, Washington: JOS Press, $2012-2015$.

https://doi:10.3233/978-1-60750-031-5-2012

12. Minno, M., Persio, R. \& Petrella, F. (2015) Finite element modeling of a piled raft for a tall building on cohesionless soil. Proc. of the XVI ECSMGE Geotechnical Engineering for Infrastructure and Development. Edinburg, 4019 4024.

https://doi/abs/10.1680/ecsmge. 60678
- rupture of the main thermal pipeline, which led to the occurrence of the "negative friction" effect (pile overloading due to the settlement of the surrounding soil, causing forces to act downwards on the pile) along the lateral surface of the piles;

- the impact of inertial forces from career explosions.

4. The technical condition of the pile foundations was estimated as unsatisfactory, and therefore, to ensure the further operation of the building, an appropriate project was developed to provide a set of measures, the main of which is the pile foundations' strengthening under the left end block section by extending at least $400 \mathrm{~mm}$ thick monolith reinforced concrete plate under the existing grids, by the divisions, and in stages. To incorporate the plate "into the framework" it is necessary to compact the base under the plate immediately after its completion. foundations of buildings under reconstruction. Moscow: Publishing house ASV.

2. Polishchuk, A.I. (2004) Design fundamentals of foundations of buildings under reconstruction. Northampton: STT; Tomsk: STT.

3. Ulitskii, V.M., Shashkin, A.H. \& Shashkin, K.H. (2010) Geotechnical provision of urban development. Saint-Petersburg: Georeconstruction.

4. Briaud, J.-L. (2013). Geotechnical Engineering: Unsaturated and Saturated Soils. Wiley.

5. Ilyichev, V.A. \& Mangushev, R.A. (Ed.) (2014). Handbook of geotechnics. Bases, foundations and underground structures. Moscow: Publishing house ASV.

6. Katzenbach, R., Leppla, S., Seip, M. \& Kurze, S. (2015) Value Engineering as a basis for safe, optimized and sustainable design of geotechnical structures. Proc. of the XVI ECSMGE Geotechnical Engineering for Infrastructure and Development. Edinburg, $601-606$.

https://doi/abs/10.1680/ecsmge.60678

7. Zotsenko, M.L. \& Vynnykov, Yu.L. (2019). Nonexcavated foundations. Poltava: PoltNTU.

8. Tugaenko, Yu.F. (2008) Soil deformation processes in the base of foundations, piles and pile foundations. Odessa: Astroprint.

9. Fleming, K., Weltman, A., Randolph, M. \& Elson, K. (2008) Piling Engineering. London: New York: Taylor and Francis.

10. Sotnikov, S.N. (1987). Construction and reconstruction of foundations of buildings and structures on soft soils. (DSc in Engineering). VNIIOSP, Moscow.

11. Won, J.Y. (2009) A probabilistic aproach to estimate one-dimensional consolidation settlements. Proc. of the 17th Intern. Conf. on Soil Mechanics and Geotechnical Engineering. Olexandria, Egypt, 2009. - Amsterdam, Berlin, Tokyo, Washington: JOS Press, $2012-2015$. https://doi:10.3233/978-1-60750-031-5-2012

12. Minno, M., Persio, R. \& Petrella, F. (2015) Finite element modeling of a piled raft for a tall building on cohesionless soil. Proc. of the XVI ECSMGE Geotechnical Engineering for Infrastructure and Development. Edinburg, 4019 4024 .

https://doi/abs/10.1680/ecsmge. 60678 
13. Vynnykov, Y., Voskobiinyk O., Kharchenko, M. \& Marchenko, V. (2017). Probabilistic analysis of deformed mode of engineering constructions' soil-cement grounds. Materials Science, Engineering and Chemistry. - MATEC Web of Conf. Proc. of the 6th Intern. Scientific Conf. "Reliability and Durability of Railway Transport Engineering Structures and Buildings" (Transbud-2017), 116.

https://doi.org/10.1051/matecconf/201711602038

14. Zotsenko, N.L. \& Vynnykov Yu.L. (2016). Long-Term Settlement of Buildings Erected on Driven Cast-In-Situ Piles in Loess Soil. Soil Mechanics and Foundation Engineering, 53(3), 189-195.

https://doi.org/10.1007/s11204-016-9384-6

15. Vynnykov, Yu., Hajiyev, M., Aniskin, A. \& Miroshnychenko, I. (2019) Improvement of settlement calculations of building foundations by increasing the reliability of determining soil compressibility indices / // Academic Journal. Series: Industrial Machine Building, Civil Engineering. Poltava: PoltNTU. 1(52)', 115 - 123.

https://doi.org/10.26906/znp.2019.52.1684

16. Самородов, А.В. (2017). Проектирование эффективных комбинированных свайных и плитных фундаментов многоэтажных зданий. Харьков: Мадрид.

17. Zotsenko, M.L., Vynnykov, Yu.L., Pinchuk, N.M. \& Manzhalii, S.M. (2019) Research of "influence area" parameters of the foundations arranged without soil. TRANSBUD2019. IOP Conf. Series: Materials Science and Engineering. 708 (2019) 012076 IOP Publishing.

https://doi:10.1088/1757-899X/708/1/012076
13. Vynnykov, Y., Voskobiinyk O., Kharchenko, M. \& Marchenko, V. (2017). Probabilistic analysis of deformed mode of engineering constructions' soil-cement grounds. Materials Science, Engineering and Chemistry. - MATEC Web of Conf. Proc. of the 6th Intern. Scientific Conf. "Reliability and Durability of Railway Transport Engineering Structures and Buildings" (Transbud-2017), 116.

https://doi.org/10.1051/matecconf/201711602038

14. Zotsenko, N.L. \& Vynnykov Yu.L. (2016). Long-Term Settlement of Buildings Erected on Driven Cast-In-Situ Piles in Loess Soil. Soil Mechanics and Foundation Engineering, 53(3), 189-195.

https://doi.org/10.1007/s11204-016-9384-6

15. Vynnykov, Yu., Hajiyev, M., Aniskin, A. \& Miroshnychenko, I. (2019) Improvement of settlement calculations of building foundations by increasing the reliability of determining soil compressibility indices / // Academic Journal. Series: Industrial Machine Building, Civil Engineering. Poltava: PoltNTU. 1(52)', 115 - 123.

https://doi.org/10.26906/znp.2019.52.1684

16. Samorodov, A.V. (2017). Designing the effective combined pile and plate foundations of multi-storey buildings. Kharkiv: Madrid.

17. Zotsenko, M.L., Vynnykov, Yu.L., Pinchuk, N.M. \& Manzhalii, S.M. (2019) Research of "influence area" parameters of the foundations arranged without soil. TRANSBUD2019. IOP Conf. Series: Materials Science and Engineering. 708 (2019) 012076 IOP Publishing. https://doi:10.1088/1757-899X/708/1/012076 